Mr. Sauvé was elected Chairman of the House of Commons Special Committee on Defense, in June 1963. He was appointed Privy Councillor and Minister of Forestry on February 3, 1964.

In 1948, he married the former Jeanne Benoit of Ottawa. They have a four-year-old son, Jean-François.

\title{
Dr. J. H. Jenkins Wins 1963 Wood Award
}

Dr. J. H. Jenkins, O.B.E., Director of Forest Products Research for the Department of Forestry, was a recipient of the 1963 Wood Award of the Canadian Lumbermen's Association, at the group's annual meeting held in Montreal in February. This is the first time the Association has so honoured a federal government employee or anyone outside the industry.

The award was presented to Dr. Jenkins "in recognition of his long and meritorious service to the development and progress of Canada's lumber industry and of the outstanding leadership he has continually shown". The award carries the signatures of the President, L. McKimmie and SecretaryManager, D. D. Lockhart.

\section{Advanced Study Institute on Genetic Improvement for Disease} and Insect Resistance of Forest Trees

A meeting will be held at The Pennsylvania State University, State College, Pennsylvania, from August 30 to September 11, 1964.

Sponsored by the North Atlantic Treaty Organization and the National Science Foundation, the Institute will bring together scientists from many countries. Specialists in genetics, entomology, and pathology will review significant original research, and discuss approaches and methodology in breeding for pest resistance of forest trees. The Northeastern Forest Tree Improvement Conference will hold its annual meeting in conjunction with the Institute.

Ernst J. Schreiner of the U.S. Forest Service and Jack A. Winieski of the Pennsylvania Department of Forests and Waters serve on the organizing committee with R. E. McDermott and Henry D. Gerhold of the School of Forestry, who are co-directors of the Institute.

Further information may be obtained from H. D. Gerhold, School of Forestry, University Park, Pennsylvania, 16802, U.S.A.

The World's Forestry Literature: A New Library Service From Oxford

An important new library service has just been inaugurated by the Commonwealth Forestry Institute, Oxford. Thanks to a grant of 75,000 dollars from the Ford Foundation of New York the contents of a unique library will become available internationally on microfilm.

The Commonwealth Forestry Institute's Library has existed since 1908 and a continuing policy of collecting forest literature from all countries has made it probably the most comprehensive forest library in existence.

Four main types of material make up the collection. First, there is a comprehensive card catalogue of world forestry literature classified and cross-referenced according to the internationally accepted "Oxford Decimal System". This is produced in collaboration with the Commonwealth Forestry Bureau and current entries form the basis of the familiar Forestry Abstracts. 